\title{
Correlation Study of Enculturations Surah Ash Shaff : 10-11 with Spiritual Quotient A Case Study
}

\author{
Julianto Hutasuhut*, Al Kausar Saragih \\ Faculty of Economics, Universitas Muslim Nusantara AI-Wasliyah, Medan, Indonesia \\ *Corresponding Author: juliantohts@umnaw.ac.id, alsaragih@umnaw.ac.id
}

How to Cite: Hutasuhut, J., Saragih, A., K. (2020). Correlation Study of Enculturations Surah Ash Shaff : 10-11 with Spiritual Quotient A Case Study. International Journal for Educational and Vocational Studies, 2(5), 537-541. DOI: https://doi.org/10.29103/ijevs.v2i5.2498

\section{ARTICLE HISTORY}

Received: 18 February 2020

Revised: 27 April 2020

Accepted: 13 May 2020

KEYWORDS

Surah Ash Shaff :

10-11 Enculturation;

Spiritual Quotient;

\begin{abstract}
In an effort to create a national cultural agenda of "Towards a Superior Indonesia", the concept of human resources development should be reconstructed to lead to the new concept of focusing on the development of spiritual quotient $(\mathrm{SQ})$. The main reason for this is that the concept of $S Q$ is the highest human intelligence that enables IQ and EQ to function effectively. The purpose of this study was to find out the correlation of Surah Ash Shaff: 10-11 enculturation through memorizing and reading it at each commencement of the lecture with the spritual quotient of the students at Faculty of Economics, Universitas Muslim Nusantara AI-Washliyah. The type of research used is assosiaitive research with quantitative approach. The study population are students of the Faculty of Economics, Universitas Muslim Nusantara AI-Washliyah/sample and sample size was set 165 people with purposive sampling technique. The data collection tool used was a questionnaire using Likert scale measurement. The data analysis techniques used were validity test, reliability test, classical assumption test, correlation test and to test hypothesis using Pearson correlation test and Spearman's correlation test as well as the coefficient of deterioration test ( $R$ test). The results of the coefficient of determination ( $R$ test) concluded, the contribution of the Surah Ash Shaff: 10-11 enculturation was able to explain the spiritual quotient variable by $65.8 \%$ while the other contribution of $34.2 \%$ was influenced by the other variables.
\end{abstract}

This is an open access article under the CC-BY-SA license.

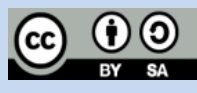

\section{INTRODUCTION}

Scientific studies of spiritual intelligence (SQ) only began to develop in the early 2000s in America and Europe with the characters Zohar and Marshall. The background of the problem being researched is the phenomenon that more and more professionals are complaining about work life. Those who succeeded in a career, living in a well-rounded life did not guarantee to be able to live a calm and more meaningful life. Even some of the people who were sampled complained about the emptiness of the soul, the boredom of life and the future did not know the direction of life that would be achieved.

Based the study, Zohar and Marshall stated that SQ is an individual intelligence that functions to help someone in facing and solving various problems about the meaning and value of life. SQ also has the potential to place a person's behavior and life in the context of a broader and richer meaning, so that this intelligence can assess that one's actions or way of life are higher in meaning and value compared to other individuals. [1] The same thing was also explained by Ginanjar, that spiritual intelligence (SQ) is the foundation needed by individuals to be able to function
IQ (intelligence intelligence) and EQ (emotional intelligence) in order to function effectively. Therefore SQ (spiritual intelligence) can be said to be the highest intelligence of humans because SQ will increase the ability to give spiritual values and meaning to thoughts, behaviors and activities, and strengthen the synergy between IQ, EQ and SQ comprehensively. So from these two explanations, it can be said that spiritual intelligence (SQ) is the core of the three concepts of human intelligence and most potential to lead humans to have more meaningful and high-value lives such as doing good deeds and always doing good to fellow beings, not cheating, not arrogant, and always accustomed to behaving based on true values of life.

Given the concept of human resource development in Indonesia that has been crossed over to the concept of IQ, and by looking at the phenomenon of an increasingly complex work environment, it is time for the national education system to shift to the latest concept by making the development of spiritual intelligence as the main foundation for intellectual intelligence (IQ) and intelligence emotional (EQ) can function effectively. That produces hu- 
man resources who not only know how to do things. But it must be able to wisely choose and sort out what is best done so that it is beneficial not for yourself but also for others and the environment. Culture is a derivative word from the word culture which generally means something that is habitual and difficult to change and is a way of life that develops in a community. The culture is shared in a community group and then passed on from one generation to the next. Examining cultural understanding is essentially a mind or mind that is formed from several basic elements such as customs, tools, language, buildings, clothing, artwork and religious systems and political systems. : 1 . The process, method, act of civilizing; 2 . The process of all social culture into a custom or a steady institution. So it can be said that culture or enculturation is one part of the cultural process, namely the activity of learning cultural values and norms experienced by individuals during their lives.

Scientifically the definition of civilization or enculturation includes: Samovar, Porter, \& McDaniel in Azeharie said that culture or enculturation is a process of learning a total culture which is also a way of learning a culture through the use of symbols, verbal and nonverbal language. Koentjaraningrat also explained that culture or enculturation is a learning process to adjust the minds and attitudes of individuals to the system of norms, customs and regulations in their culture. Furthermore, he also emphasized that the learning process that takes place in society consists of three types, namely internalization, socialization and enculturation.

In the Qur'an the Surah Ass-Shaff is contained in the 61st surah which is part of the surah Madaniyah and consists of 14 verses. This surah is called Ash Shaff, because in verse 4 there is the word Shaffan which means "one line". Next in Surah Ash-Shaff: 10 Allah says: yaa ayyuhaa alladziina aamanuu things adullukum 'alaa tijaaratin tunjiikum min'adzaabin aliimin. The word "tijaroh" in the verse means that trade is based on sholeh charity. Indeed in the Qur'an the word tijaroh is often used whose meaning is motivation to do good deeds and to get rewarded rewards, which can then be analogous to such businesses or businesses run by humans with the aim of seeking or getting profits. The background to the decline of this verse (Asbabun Nuzul) is as described by one of the scholars, the Muslims at the time asked: "If we knew what was meant by the word tijaarah we would definitely do and follow it along with family experts". So then Allah explained and answered by lowering verse 11 of Surah Ash Shaff, namely: Tu'minuuna biallaahi warasuulihi watu jaahiduuna fiisabiiliallaahi biamwaalikum waanfusikum dzaalikum khayrun lakum in kuntum ta'lamuuna. [6] what is meant by tijaarah is. believing in Allah, believing in His Messenger and striving in His way that is with wealth and soul.

\section{Research Method}

\subsection{Research Flow}

The flow of research is the structuring or methodological relationships of the stages of research activities on an ongoing basis. The flow of research must also explain the procedural chronology that will be carried out by a researcher so that the research results obtained can provide results that have high credibility.

The initial phase of the research starts from the study of literature, the selection of titles or the preparation of research models (variables), the determination of research indicators, data collection, data analysis, research results and conclusions and reporting. A description of the research flow can be seen in the following image.

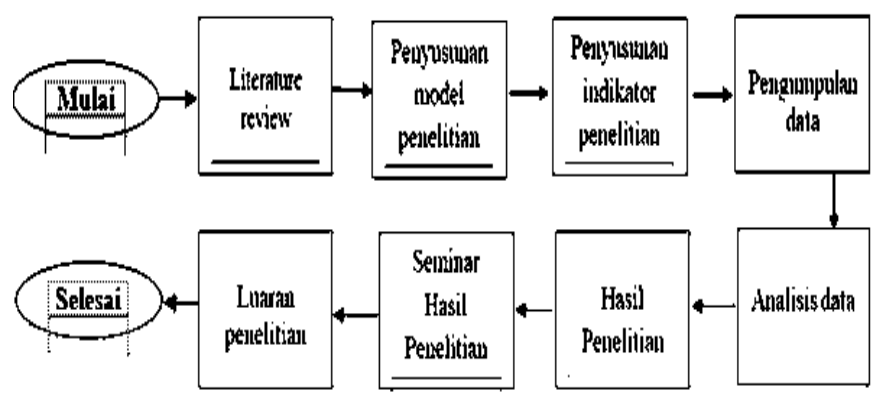

Figure 1. Research Flow

\subsection{Research Design}

A study will not find good results without a good design because research design is a strategy to make it easier for researchers to achieve the goals set. Research designs are often also referred to as research methods which include research variables, research models used, data collection techniques, data analysis techniques and ways of interpreting or testing hypotheses.

The variable to be examined is the culture of surah Ash Shaff: $10-11$ as the independent variable (X) and the spiritual intelligence variable as the dependent variable (Y). Based on the level of explanation (explanation) the type of research chosen is associative research with a quantitative approach. And according to how to obtain the type of data used is secondary data and based on its nature this study uses quantitative data. Data collection tools used were questionnaires. The data analysis technique chosen is the validity test, reliability test, normality test and heteroscedasticity test. To predict the relationship between the selected statistical test variables is the correlation method using the Pearson correlation approach and Spearman's correlation test and to test the hypothesis used the coefficient of determination test (Test R).

This study will further analyze the correlation between surah Ash Shaff civilization variables: 10-11 (X) with the spiritual intelligence variable $(\mathrm{Y})$. The relationship between the two variables $\mathrm{X}$ and $\mathrm{Y}$ can be described 


\section{RESULTS AND DISCUSSIONS}

In Primary data obtained from the sample and after being collected are then analyzed by the stages of the process of sorting, editing, scoring and tabulating. The data is then analyzed statistically with the help of SPSS software. The analysis goes through the following stages:

\section{Data Quality Test}

Before the questionnaire is used it should be tested on a number of respondents outside the sample. Data quality test in general can be done by using validity and reliability testing techniques.

\section{Validity Test}

A research instrument can be said to be valid if the instrument (measuring instrument) is able to reveal variable data to be studied or able to measure what should be measured. Data validity can be done by comparing the Corrected Item-Total Correlation ( $r$ hitumg) value with $r$ table. If the value of $r$ count $>$ table $r$, then a question can be said to be valid. The basis for decision making refers to Sugiyono's opinion with the following criteria:
- If $r>0.30$, then the question items from the questionnaire are valid.

- If $r<0.30$, then the question items from the questionnaire are invalid. [11]

SPSS output in table $\mathrm{x}$ provide information there are 4 items that are invalid because it has a value of $r$ count smaller than table $r$ or smaller than the selected criteria that is $<0.30$. These questions are question number 1 , number 5, number 6 and number 11 and must be excluded from the questionnaire that will be used as a data collection tool. So it can be said the number of item questions that are feasible to use to measure variable $\mathrm{X}$ is set to be 10 question points.

The SPSS output in table y explains that there are 5 invalid question items because they have a smaller $\mathrm{r}$ count value than the $r$ table or the smaller criteria chosen are < 0.30 . The questions are question number 1 , number 5 , number $6 \mathrm{n}$ number 11 and number 15 and must be removed from the questionnaire that will be used as a data collection tool. So it can be said the number of item questions that are feasible to use to measure the $\mathrm{Y}$ variable is set to be 10 question items.

Table 1. Variable Validity Test $X$

\begin{tabular}{cccccc}
\hline No & Variance & Scale mean is item Deleted & $\begin{array}{c}\text { Scale Variance if Item } \\
\text { Deleted }\end{array}$ & $\begin{array}{c}\text { Corrected Item Total } \\
\text { Correlation }\end{array}$ & $\begin{array}{c}\text { Cronbach's Alpha if Item } \\
\text { Deleted }\end{array}$ \\
\hline 1 & VAR0001 & 51,0400 & 35,707 & 0,232 & 0,381 \\
\hline 2 & VAR0002 & 51,6400 & 31,740 & 0,622 & 0,805 \\
\hline 3 & VAR0003 & 51,6000 & 33,750 & 0,473 & 0,818 \\
\hline 4 & VAR0004 & 51,6000 & 32,417 & 0,460 & 0,818 \\
\hline 5 & VAR0005 & 51,3200 & 34,227 & 0,291 & 0,830 \\
\hline 6 & VAR0006 & 51,7200 & 33,877 & 0,259 & 0,835 \\
\hline 7 & VAR0007 & 51,8000 & 33,917 & 0,418 & 0,797 \\
\hline 8 & VAR0008 & 51,8000 & 29,833 & 0,823 \\
\hline 9 & VAR0009 & 51,3200 & 33,727 & 0,725 & 0,804 \\
\hline 10 & VAR00010 & 51,7600 & 30,273 & 0,643 & 0,842 \\
\hline 11 & VAR00011 & 51,1600 & 37,140 & 0,017 & 0,809 \\
\hline 12 & VAR00012 & 51,6000 & 32,250 & 0,618 & 0,801 \\
\hline 13 & VAR00013 & 51,6800 & 29,560 & 0,666 & 0,810 \\
\hline 14 & VAR00014 & 51,7200 & 32,277 & 0,596 & \\
\hline
\end{tabular}

Table 2. Variable Validity Test Y

\begin{tabular}{cccccc}
\hline No & Variance & Scale mean is item Deleted & $\begin{array}{c}\text { Scale Variance if Item } \\
\text { Deleted }\end{array}$ & $\begin{array}{c}\text { Corrected Item Total } \\
\text { Correlation }\end{array}$ & $\begin{array}{c}\text { Cronbach's Alpha if Item } \\
\text { Deleted }\end{array}$ \\
\hline 1 & VAR0001 & 54,8800 & 37,777 & 0,132 & 0,821 \\
\hline 2 & VAR0002 & 55,4400 & 33,423 & 0,609 & 0,793 \\
\hline 3 & VAR0003 & 55,4400 & 33,750 & 0,473 & 0,818 \\
\hline 4 & VAR0004 & 55,4000 & 32,417 & 0,460 & 0,818 \\
\hline 5 & VAR0005 & 55,2000 & 34,227 & 0,291 & 0,830 \\
\hline 6 & VAR0006 & 55,4800 & 33,877 & 0,259 & 0,835 \\
\hline 7 & VAR0007 & 55,5600 & 33,917 & 0,418 & 0,821 \\
\hline 8 & VAR0008 & 55,6000 & 29,833 & 0,725 & 0,797 \\
\hline 9 & VAR0009 & 55,0400 & 33,727 & 0,380 & 0,823 \\
\hline 10 & VAR00010 & 55,5600 & 30,273 & 0,643 & 0,804 \\
\hline 11 & VAR00011 & 55,0000 & 37,140 & 0,017 & 0,842 \\
\hline 12 & VAR00012 & 55,4400 & 32,250 & 0,618 & 0,809 \\
\hline 13 & VAR00013 & 55,4800 & 29,560 & 0,666 & 0,801 \\
\hline 14 & VAR00014 & 55,6000 & 32,277 & 0,596 & 0,810 \\
\hline 15 & VAR00015 & 55,3600 & 36,990 & 0,196 & 0,819 \\
\hline
\end{tabular}


Reliability is an index that explains the extent to which a measuring instrument (instrument) can be trusted or consistent to measure what should be measured. If a measuring instrument is used repeatedly and produces symptoms that are relatively consistent then the measuring instrument can be said to be reliable. In this study, the reliability test refers to Ghozali's opinion, with the criteria for an instrument to be categorized as reliable if the Cronbach Alpha coefficient value is greater than 0.6. The Cronbach Alpha value can be seen in the SPSS Total Item Statistics Output.

SPSS output. explain the value of $r$ alpha $>$ table $r$ that is 0.829 greater 0.60 . Then it can be stated the item questions that will be included in the questionnaire as a data collection tool are included in the reliable category because it has a high consistency and can be trusted (reliable) to measure the variable of civilization surah Ash shaff: 10-11 (X). SPSS output. explain the value of $r$ alpha> table $r$ that is 0.816 greater 0.60 . Then it can be stated the item question that will be included in the questionnaire as a data collection tool is included in the reliable category because it has a high consistency and can be trusted (reliable) to measure the variable of spiritual intelligence (Y) on students of FE Muslim University of Al-Washliyah

\section{Normality test}

Normality test aims to determine whether the research data has a normal distribution and in accordance with the rules of the normal curve. The normality test in this case is analyzed by using the Histogram and Normal P-P (Propability Plot) of Standardized Regression approach.

a. Histogram Graph

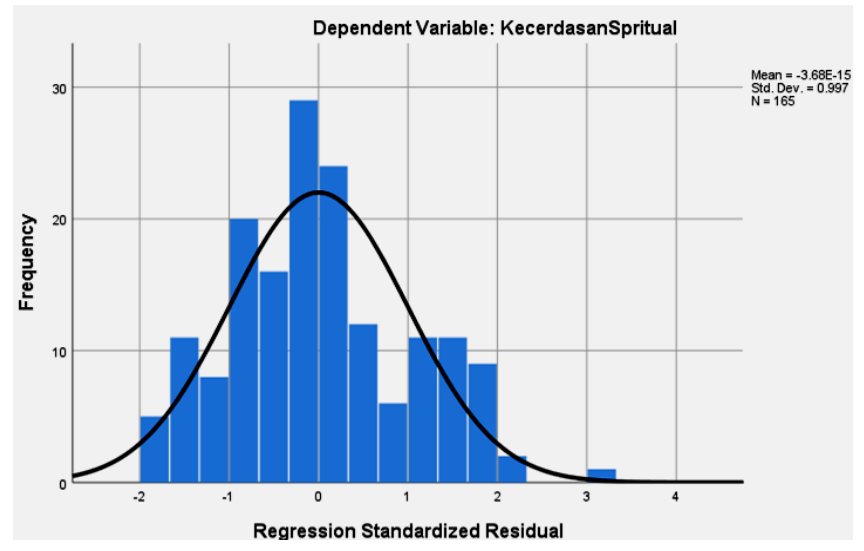

Figure 1. Histogram Chart Bar

SPSS output in Figure 4.1 explains, the spread of data does not tilt left or right so that it can be stated that the data distribution is in accordance with the normal curve rules. b. P-P Plot Normal Chart

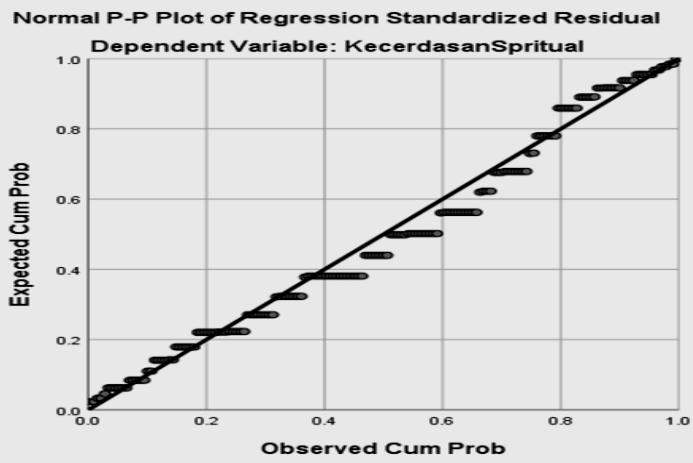

The greater the value of $\mathrm{R}$, the better the model chosen to provide the information needed from a study and the range of $R$ values is $0-1$. The Model Summary table in column $\mathrm{R}$ shows the value of 0.811 with the interpretation of the two variables having a high enough correlation. Then based on the analysis, it can be said that the variation of the culture variable of surah Ash shaff: 10-11 has a very strong level of relationship with the spiritual intelligence of students at the FE UMN Al-Washliyah. Adjusted R Square value $=0.658$, meaning that $65.8 \%$ of the variables of spiritual intelligence can be explained by acculturation of Surah Ash Shaff: 10-11 while other contributions of $34.2 \%$ are influenced by other factors outside the study of this study. In other words the research sample is able to provide the information needed by this study with a contribution of $65.8 \%$, Table Model Summary column Std. Error of the Estimate (SEE) shows the value of $\mathrm{SEE}=1,302$ and close to 0. It means that the ability of Surah Ash Shaff's civilizing variable to predict the level of spiritual intelligence is high because the smaller the SEE value or the closer it is to 0 , the better the model chosen to predict the level of spiritual intelligence of students of the Faculty of Economics UMN Al-Washliyah

\section{CONCLUSION}

Based on the analysis in the previous chapter, the authors draw conclusions which include:

1. Pearson correlation test results explain that the cultivation of surah Ash shaff: 10-11 has a very strong level of relationship with spiritual intelligence which is at the level of 0.813. Based on the Spearman correlation test, culture of Sura Ash Shaff: 10-11 has a strong relationship level which is at the level of 0.723 .

2. Based on the $\mathrm{R}$ test it is known that the correlation value $(R)=0.811$ which can be interpreted has a fairly high correlation. This means that the chosen variable variation is the culture of surah Ash Shaff: 10-11 has a very strong level of relationship with the spiritual intelligence of students at the Faculty of Economics UMN Al-Washliyah. Based on the R Square test, it is known that the Adjusted $\mathrm{R}$ Square value $=0.658$, meaning that $65.8 \%$ of the students' spiritual intelligence variables can be explained by civilizing Surah Ash Sshaff: 10-11 while the remaining $34.2 \%$ is influenced by other factors outside the research study. this.

Based on the analysis of the frequency of answers, it is known that the highest score for the answer to variable $\mathrm{X}$ 
is item X.1 with a score of 805 , meaning that most respondents have a strong belief (faith) that the only God entitled to worship is Allah SWT. The lowest score for variable $\mathrm{X}^{\prime}$ 's answer is item X.10 with a score of 678 . It can be said that the respondent's understanding of the meaning of jihad with the soul needs to be further improved. The highest score for the variable $\mathrm{Y}$ answers is for item Y.6 with a score of 762 , meaning that most of the samples have a high understanding that whatever humans do the result is the power of Allah SWT. The lowest score for the variable Y answer is item Y.8 with a score of 706 , meaning that most of the sample lack understanding of the dangers of filing, slandering, hating and feeling vengeful.

\section{REFERENCES}

Zohar, Danah dan Marshall, Ian. Terjemahan Rahmani Astuti dkk., (2007). Kecerdasan Spiritual. Bandung: Mizan.H.4

KKBI: https://typoonline.com/kbbi/ pembudayaan

Azeharie, Suzy et al. (2019). Studi Budaya Nonmaterial Warga Jaton. Jurnal ASPIKOM, Vol. 3, No. 6, 1153-1162

Koentjaraningrat, (2012).Pengantar Antropologi. Jakarta. Rineka. Hal.184

Muhaimin. (2009). Rekontruksi Pendidikan Islam (Dari ParadigmaPengembanganManajemen Kelembagaan, Kurikulum Hingga Strategi Pembelajaran). Jakarta: Raja Grafindo Persada.

DEPAG RI., (2015). Al-Kafi Mushaf Al-Qur'an. Bandung. Diponegoro, Hal.552. Surah Ash Shaff

Fitri, Ridho Nurul (2016). Pengaruh Pembentukan Karakter dengan Kecerdasan Spiritual di SMA Negeri 22 Palembang. Jurnal: Intelektualita, Vol.5, No1, 110-118

Siswanto, Wahyudi. (2012). Membenntuk Kecerdasan Spiritual Anak. Jakarta: Amzah. Hal. 10

Ginanjar, A.Austian, (2008). ESQ : Emotional Spritual Question. Jakarta: Arga, Hal. 46

Supriyanto, Achmad Sani, (2012). Pengaruh Kecerdasan Emosional dan Kecerdasan Spiritual terhadap Kepemimpinan Transformasional, Kepuasan Kerja dan Kinerja Manajer (Studi di Bank Syariah Kota Malang). Malang. Jurnal Aplikasi Manajemen,Vol.10, No:4, 693-709

Sugiyono, (2014). Metode Penelitian Pendidikan Pendekatan Kuantitatif, Kualitatif, dan R\&D. Bandung: Alfabeta. Hal.172

Ghozali, Imam. (2013). Aplikasi Analisis Multivariate dengan program IBM SPSS19. Semarang: Badan Penerbit Universitas Diponegoro. Hal. 52. 